\title{
Study of the microbiological activity in the agrocenosis from Crisurilor Plain
}

\author{
Aurelia Onet - Cristian Onet \\ University of Oradea, Faculty of Environmental Protection, Oradea \\ aurelia_onet@yahoo.com
}

$S U M M A R Y$

\begin{abstract}
The seasonal variations of soil microorganisms depend on changes in the soil chemical properties and the microbiological processes of soil are determined in main by different cropping systems, soil management and season. Investigation of the microbiological properties of a haplic luvisol, under different cultivation conditions showed that anthropogenic factors such as fertilization and treatments with pesticides was favourable for certain microorganisms while others were inhibited by these factors. In order the quantitative occurence of microorganism was aerobic mesophilic heterotrophs $\left(10^{5}-10^{7}\right.$ cells $\times \mathrm{g}^{-1}$ dry matter soil) were followed by Actinomycetes, yeast and mould $\left(10^{3}-10^{6}\right.$ cells $\times \mathrm{g}^{-1}$ dry matter soil), nitrogen fixing bacteria $\left(10^{2}-10^{5}\right.$ cells $\times \mathrm{g}^{-1}$ dry matter soil) and nitrifying bacteria $\left(10^{-1}-10^{3}\right.$ cells $\times \mathrm{g}^{-1}$ dry matter soil). The highest values of aerobic mesophilic heterotrophs were found in cropland and undisturbed meadow of haplic luvisol. Actinomycetes are more developed in undisturbed soils than in the cultivated soils. The number of yeast and mould was high in the apricot tree orchard, and Azotobacter and nitrifying bacteria were identified in a small number in all the soil variants studied. Among the total number of aerobic microorganisms, $p H$ and humus content statistically proved relationship was established. Total number of yeast and mould depends on the proportion of $10.89 \%$ by moisture content and $\mathrm{pH}$. The numerical presence of Azotobacter depends in a proportion of $9.6 \%$ by the ammonia nitrogen content and pH variations. The numerical presence of nitrifying bacteria depends in a proportion of $1.69 \%$ by the nitric nitrogen content and humus content variation.
\end{abstract}

Keywords: microbiological activity, agrocenosis, soil

\section{INTRODUCTION}

The productiveness of soil and his autopurification capacity are provided, in main, by the microbiological activity. Anthropogenic factors as irrigation, fertilization, treatments with pesticides, and processing of soil, can affect the microorganisms of soil. Microbiological properties can serve as soil quality indicators because after plants soil microbes are the second most important biological agent of the agricultural ecosystem. Soil microorganisms can be used to assess soil quality or degradation. Many discussions deal with the effect of farming practices, such as the influence of the use of chemical fertilizers and pesticides on soil microorganisms and environmental quality (Digrak, 1999).

\section{MATERIAL AND METHODS}

The researches were carried out in 2010 and 2011 on the haplic luvisol cultivated in three variant such as: cropland (cultivated in 2010 with wheat and in 2011 with maize), orchards and pasture. Soil samples were collected from plots of an experimental field localized at 10 kilometers from Oradea, at village Cauaceu. The agricultural use of cultivated orchards are always applied chemical fertilizers and treatment with pesticides but the untilled soil from pasture has not got any history pesticides or fertilizers (Onet, 2010). In the laboratory plant material and soil macro fauna were removed and the soil samples were sieved $(<2 \mathrm{~mm})$ and mixed. Some physical and chemical properties of the soil samples were determined as follows: soil moisture using gravimetrically method by oven-drying fresh soil at $105^{\circ} \mathrm{C}, \mathrm{pH}$ in $1: 2: 5$ soil water suspension by $\mathrm{pH}-$ meter, organic material by using Walkley-Black method, nitrate $\left(\mathrm{NO}_{3}-\mathrm{N}\right)$ determination by colorimetric method and ammonium with Nessler reagent. Total number of aerobic mesophilic heterotrophs, Actinomycetes, yeast-mold, nitrogen fixing bacteria and nitrifying bacteria were determined using the dilution method. The soil samples $(10 \mathrm{~g})$ were suspended in $90 \mathrm{ml}$ distilled water. Dilutions (of $10^{-6}$ ) were prepared from the soil samples using distilled water and these were dispersed with a top drive shaker for $5 \mathrm{~min}$. The soil samples taken from suitable dilution were planted in or on the solid or liquid feeding medium as required (Onet, 2011).

Plate count method was used to estimate total number of microorganisms on a solid nutrient medium containing meat extract (Atlas, 2004), total number of Actinomycetes on agar with glucose and asparagines and total number of yeast-mold on Sabouraud Agar. Also, total number of Azotobacter was cultured on Ashby's glucose agar. After incubation the counts obtained were multiplied by the dilution factor to obtain the number of colony forming unit per gramme of soil. To estimate the number of nitrifying bacteria the most probable number method (MPN) was used. Nitrate and nitrite-forming bacteria were cultured in a liquid culture medium containing Winogradsky's salt solution. (DraganBularda and Kiss, 1986). After incubation the most probable number of nitrifying bacteria was calculated according to the statistical table of Alexander (1965). The results were analyzed with the "Student" statistics method to determine the significance or non-significance of the differences between the values. Also was calculated the multiple correlation coefficient and $F$ values based on the global significance test $\mathrm{F}$ and the determination coefficient showing the proportion in which numerical microorganisms variations depends by the changes of chemical soil indicators.

\section{RESULTS AND DISCUSSION}

The highest moisture content was measured in cropland, in comparison with pasture and orchards (table 1). In orchards were registered the lowest $\mathrm{pH}$ 
values (5.70-6.55) in comparison with cropland where the values were higher (6.65-8.00) (table 2). The concentration of $\mathrm{N}-\mathrm{NO}_{3}$ was higher in cropland showing that the process of nitrification is more developed in this soil (table 3). As it can be seen in table 4 the orchards presented in both profile of the soil $(0-20,20-40)$ content in $\mathrm{N}-\mathrm{NH}_{4}$ higher in comparison with cropland and pasture (table 4). The highest values of the humus content were found in the cropland in comparison with other variants (table 5).

The number of bacteria decreases in the order: aerobic mesophilic heterotrophs $\left(10^{5}-10^{7}\right.$ cells $\times \mathrm{g}^{-1}$ dry matter soil $)>$ Actinomycetes, yeast and mould $\left(10^{3}-\right.$ $10^{6}$ cells $\times \mathrm{g}^{-1}$ dry matter soil $)>$ nitrogen fixing bacteria $\left(10^{2}-10^{5}\right.$ cells $\times \mathrm{g}^{-1}$ dry matter soil $)>$ nitrifying bacteria $\left(10^{-1}-10^{3}\right.$ cells $\times \mathrm{g}^{-1}$ dry matter soil) (table 6).

Table 1.

Haplic luvisol moisture content (\%)

\begin{tabular}{rlrrrr}
\hline Year & $\begin{array}{c}\text { Vegetation } \\
\text { period }\end{array}$ & $\begin{array}{c}\text { Depth } \\
(\mathrm{cm})\end{array}$ & Pasture & Cropland & Orchards \\
\hline \multirow{3}{*}{2010} & Spring & $0-20$ & 14.06 & 18.50 & 16.87 \\
& & $20-40$ & 14.06 & 15.59 & 15.61 \\
& Autumn & $0-20$ & 11.76 & 15.20 & 11.10 \\
& & $20-40$ & 10.24 & 13.05 & 10.99 \\
\hline \multirow{2}{*}{2011} & Spring & $0-20$ & 12.03 & 8.90 & 12.91 \\
& & $20-40$ & 13.41 & 17.93 & 15.12 \\
& Autumn & $0-20$ & 7.09 & 7.97 & 8.96 \\
& & $20-40$ & 4.60 & 9.47 & 7.81 \\
\hline
\end{tabular}

Table 2.

pH of the haplic luvisol

\begin{tabular}{clrccc}
\hline Year & $\begin{array}{c}\text { Vegetation } \\
\text { period }\end{array}$ & $\begin{array}{c}\text { Depth } \\
(\mathrm{cm})\end{array}$ & Pasture & Cropland & Orchards \\
\hline \multirow{6}{*}{2010} & Spring & $0-20$ & 6.20 & 7.85 & 5.80 \\
& & $20-40$ & 6.25 & 7.88 & 5.75 \\
& Autumn & $0-20$ & 6.15 & 6.65 & 5.70 \\
& & $20-40$ & 6.15 & 6.80 & 5.95 \\
\hline \multirow{3}{*}{2011} & \multirow{2}{*}{ Spring } & $0-20$ & 5.85 & 7.80 & 6.55 \\
& & $20-40$ & 6.15 & 8.00 & 5.85 \\
& Autumn & $0-20$ & 6.05 & 7.80 & 6.25 \\
& & $20-40$ & 6.20 & 7.90 & 6.30 \\
\hline
\end{tabular}

Nitrates content (ppm) of the haplic luvisol

\begin{tabular}{clrrrr}
\hline Year & $\begin{array}{c}\text { Vegetation } \\
\text { period }\end{array}$ & $\begin{array}{c}\text { Depth } \\
(\mathrm{cm})\end{array}$ & Pasture & Cropland & Orchards \\
\hline \multirow{4}{*}{2010} & Spring & $0-20$ & 3.5 & 10.9 & 5.3 \\
& & $20-40$ & 3.6 & 11.1 & 4.1 \\
& Autumn & $0-20$ & 2.4 & 26.6 & 6.2 \\
& & $20-40$ & 2.4 & 13.3 & 4.6 \\
\hline \multirow{4}{*}{2011} & Spring & $0-20$ & 1.8 & 9.3 & 3.3 \\
& & $20-40$ & 1.3 & 8.4 & 3.3 \\
& Autumn & $0-20$ & 2.0 & 20.0 & 7.3 \\
& & $20-40$ & 2.1 & 18.7 & 10.3 \\
\hline
\end{tabular}

Table 4.

Ammonia nitrogen content (ppm) of the haplic luvisol

\begin{tabular}{rlrrrc}
\hline Year & $\begin{array}{c}\text { Vegetation } \\
\text { period }\end{array}$ & $\begin{array}{c}\text { Depth } \\
(\mathrm{cm})\end{array}$ & Pasture & Cropland & Orchards \\
\hline \multirow{6}{*}{2010} & Spring & $0-20$ & 1.6 & 0.6 & 2.8 \\
& & $20-40$ & 0.2 & 0.0 & 1.4 \\
& Autumn & $0-20$ & 3.3 & 0.8 & 0.7 \\
& & $20-40$ & 3.6 & 0.8 & 0.5 \\
\hline \multirow{3}{*}{2011} & \multirow{2}{*}{ Spring } & $0-20$ & 4.7 & 17.2 & 3.8 \\
& & $20-40$ & 4.3 & 5.3 & 4.2 \\
& \multirow{2}{*}{ Autumn } & $0-20$ & 4.8 & 0.5 & 0.9 \\
& & $20-40$ & 1.5 & 0.4 & 0.3 \\
\hline
\end{tabular}

Table 5.

Humus content (\%) of the haplic luvisol

\begin{tabular}{rlrrrr}
\hline Year & $\begin{array}{c}\text { Vegetation } \\
\text { period }\end{array}$ & $\begin{array}{c}\text { Depth } \\
(\mathrm{cm})\end{array}$ & Pasture & Cropland & Orchards \\
\hline \multirow{3}{*}{2010} & Spring & $0-20$ & 1.72 & 2.93 & 1.77 \\
& & $20-40$ & 1.51 & 2.34 & 1.50 \\
& Autumn & $0-20$ & 2.87 & 2.68 & 2.45 \\
& & $20-40$ & 1.82 & 2.08 & 1.82 \\
\hline \multirow{3}{*}{2011} & \multirow{2}{*}{ Spring } & $0-20$ & 3.05 & 3.26 & 2.45 \\
& & $20-40$ & 1.72 & 3.15 & 2.53 \\
& \multirow{2}{*}{ Autumn } & $0-20$ & 3.49 & 3.25 & 3.92 \\
& & $20-40$ & 2.15 & 2.63 & 2.39 \\
\hline
\end{tabular}

The evolution of soil microbiota indicate that in 2010 , in cropland and orchards presented a number of total microorganisms lower in comparison with the number of microorganisms counted in pasture $\left(p<0.05^{*}\right)$. Also, in both profile, in soil of orchards the total number of microorganisms is decreased (Onet, 2011). The treatments with pesticides and fertilizers can affect the development of microorganisms. In 2010, under the wheat culture the number of aerobic mesophilic bacteria was more higher in comparison with the number found in 2011 in the soil of maize $(\mathrm{p}<0.02 *)$. Under the maize culture the soil contained different acids due to the metabolism of Actinomycetes (oxalic and paracumaric acid) these acids and compounds have toxic substances wich inhibite the quantities of bacteria (table 7).

The development of Actinomycetes depends on the presence in soils of plant residues. These microorganisms are more developed in uncultivated soils than in the agricultural soils (table 8).

The soil of orchards presented in both profile a higher number of yeast-mold in comparison with other variants $\left(\mathrm{p}<0.05^{*}\right)$ (table 9). These microorganisms have an important role in affecting the persistence of pesticides, having the capacity for rapid elimination of highly persistent or toxic chemicals. The yeast-mold uses the pesticides such as a carbon and energy source (Onet, 2011).

The treatments with pesticides and chemical fertilizers have inhibitory effect on the living conditions of the Azotobacter. The nitrifying bacteria's have been identified just in the profile $20-40$ of the cropland and orchards. Nitrogen fixing bacteria Azotobacter and nitrifying bacteria have been identified in a small number and were not registered significant differences between the values ( $\mathrm{p}>0.10)$ (table 10). 
Quantity change of the main groups of microorganisms monitored in haplic luvisol

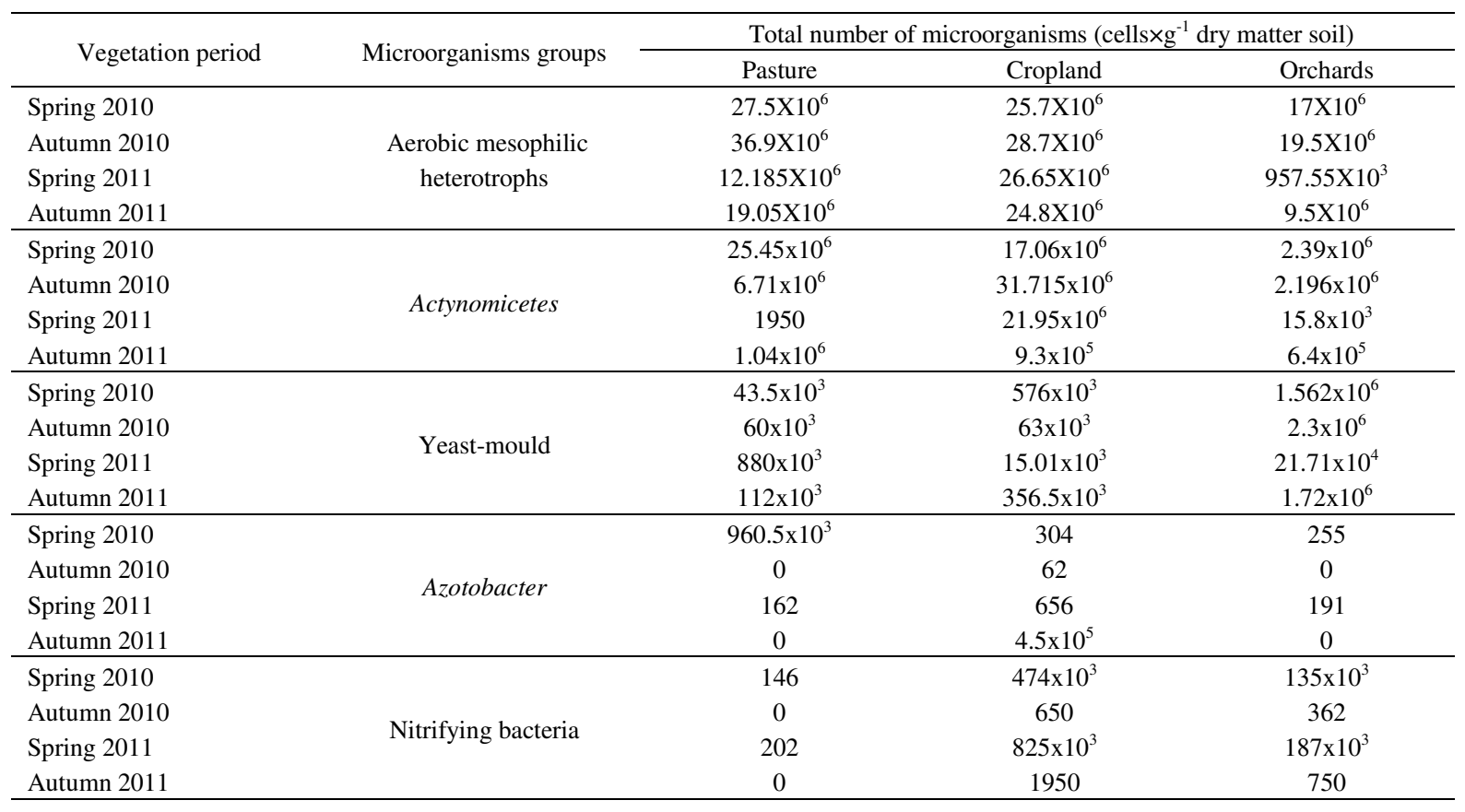

Significant differences between total number of

Table 7 . microorganisms values determined in haplic luvisol under different cultivation conditions

\begin{tabular}{clcccc}
\hline $\begin{array}{c}\text { Vegetation } \\
\text { period }\end{array}$ & $\begin{array}{c}\text { Soil } \\
\text { variant }\end{array}$ & $\begin{array}{c}\text { Depth } \\
(\mathrm{cm})\end{array}$ & $\mathrm{a}$ & $\mathrm{c}$ & $\begin{array}{c}\text { Mean values } \\
\text { of } \\
\text { sig. }\end{array}$ \\
\hline $\begin{array}{c}\text { Spring } \\
2010\end{array}$ & $\begin{array}{l}\text { Pasture (a) } \\
\text { Orchards (b) }\end{array}$ & $0-40$ & $27.5 \times 10^{6}$ & $17 \times 10^{6}$ & $\mathrm{p}<0.05^{*}$ \\
$\begin{array}{c}\text { Autumn } \\
2010\end{array}$ & $\begin{array}{l}\text { Pasture (a) } \\
\text { Orchards (b) }\end{array}$ & $0-40$ & $36.9 \times 10^{6}$ & $19.5 \times 10^{6}$ & $\mathrm{p}<0.05^{*}$ \\
$\begin{array}{c}\text { Spring } \\
2011\end{array}$ & $\begin{array}{l}\text { Pasture (a) } \\
\text { Cropland (b) }\end{array}$ & $0-40$ & $12.185 \times 10^{6}$ & $26.65 \times 10^{6}$ & $\mathrm{p}<0.05^{*}$ \\
Autumn & $\begin{array}{l}\text { Cropland (a) } \\
2011\end{array}$ & $0-40$ & $24.8 \times 10^{6}$ & $9.5 \times 10^{6}$ & $\mathrm{p}<0.05^{*}$ \\
\hline
\end{tabular}

Significant differences between total number of Actinomycetes determined in haplic luvisol under different cultivation conditions

\begin{tabular}{cccccc}
\hline $\begin{array}{c}\text { Vegetation } \\
\text { period }\end{array}$ & \multicolumn{1}{c}{$\begin{array}{c}\text { Soil } \\
\text { variant }\end{array}$} & $\begin{array}{c}\text { Depth } \\
(\mathrm{cm})\end{array}$ & $\mathrm{a}$ & $\mathrm{b}$ & $\begin{array}{c}\text { Mean values } \\
\text { of } \\
\end{array}$ \\
\hline $\begin{array}{c}\text { Sig. } \\
2010\end{array}$ & $\begin{array}{l}\text { Pasture (a) } \\
\text { Orchards (b) }\end{array}$ & $0-40$ & $25.45 \times 10^{6}$ & $2.39 \times 10^{6}$ & $\mathrm{p}<0.05^{*}$ \\
& $\begin{array}{l}\text { Pasture (a) } \\
\text { Orchards (b) }\end{array}$ & $0-40$ & $17.06 \times 10^{6}$ & $2.39 \times 10^{6}$ & $\mathrm{p}<0.05^{*}$ \\
\hline
\end{tabular}

Table 9

Significant differences between total number of yeast and mould determined in haplic luvisol under different cultivation conditions

\begin{tabular}{|c|c|c|c|c|c|}
\hline \multirow{2}{*}{$\begin{array}{c}\text { Vegetation } \\
\text { period }\end{array}$} & \multirow{2}{*}{$\begin{array}{c}\text { Cultivation } \\
\text { types of } \\
\text { haplic luvisol }\end{array}$} & \multirow{2}{*}{$\begin{array}{l}\text { Depth_ } \\
(\mathrm{cm})\end{array}$} & \multicolumn{2}{|c|}{ Mean values } & \multirow{2}{*}{$\begin{array}{l}\text { Level of } \\
\text { sig. }\end{array}$} \\
\hline & & & $\mathrm{a}$ & $\mathrm{b}$ & \\
\hline $\begin{array}{l}\text { Spring } \\
2010\end{array}$ & $\begin{array}{l}\text { Pasture (a) } \\
\text { Orchards (b) }\end{array}$ & $0-40$ & $43.5 \times 10^{3}$ & $1.562 \times 10^{6}$ & $\mathrm{p}<0.05^{*}$ \\
\hline \multirow[t]{2}{*}{$\begin{array}{c}\text { Autumn } \\
2010\end{array}$} & $\begin{array}{l}\text { Pasture (a) } \\
\text { Orchards (b) }\end{array}$ & $0-40$ & $60 \times 10^{3}$ & $2.3 \times 10^{6}$ & $\mathrm{p}<0.05^{*}$ \\
\hline & $\begin{array}{l}\text { Cropland (a) } \\
\text { Orchards (b) }\end{array}$ & $0-40$ & $63 \times 10^{3}$ & $2.3 \times 10^{6}$ & $\mathrm{p}<0.05^{*}$ \\
\hline $\begin{array}{l}\text { Spring } \\
2011\end{array}$ & $\begin{array}{l}\text { Pasture (a) } \\
\text { Cropland (b) }\end{array}$ & $0-40$ & $880 \times 10^{3}$ & $15.01 \times 10^{3}$ & $\mathrm{p}<0.05^{*}$ \\
\hline Autumn & Pasture (a) & & & & \\
\hline \multirow[t]{2}{*}{2011} & Cropland (b) & $0-40$ & $112 \times 10^{3}$ & $356.5 \times 10^{3}$ & $\mathrm{p}<0.05^{*}$ \\
\hline & $\begin{array}{l}\text { Cropland (a)/ } \\
\text { Orchards (b) }\end{array}$ & $0-40$ & $356.5 \times 10^{3}$ & $1.72 \times 10^{6}$ & $\mathrm{p}<0.05^{*}$ \\
\hline
\end{tabular}

Table 10

Significant differences between total number of nitrogen fixing bacteria determined in haplic luvisol under different cultivation conditions

\begin{tabular}{cccccc}
\hline \multirow{2}{*}{$\begin{array}{c}\text { Vegetation } \\
\text { period }\end{array}$} & $\begin{array}{c}\text { Cultivation } \\
\text { types of haplic } \\
\text { luvisol }\end{array}$ & $\begin{array}{c}\text { Depth } \\
(\mathrm{cm})\end{array}$ & $\mathrm{a}$ & $\mathrm{b}$ & $\begin{array}{c}\text { Mean values } \\
\text { of sig. }\end{array}$ \\
$\begin{array}{c}\text { Spring } \\
2010\end{array}$ & $\begin{array}{c}\text { Cropland (a) } \\
\text { Orchards (b) }\end{array}$ & $0-40$ & 304 & 255.5 & $\mathrm{p}<0.05^{*}$ \\
\hline
\end{tabular}


The number of microorganisms was higher in spring because the mineralization activity of microorganisms is more intensive in spring. Easily available organic substances of soil are significantly higher in spring than in autumn (Onet, 2011).

The correlation between total number of microorganisms, $\mathrm{pH}$ values and humus content is statistically confirmed with a significantly distinct level $(\mathrm{P}=1 \%)$. Between total number of microorganisms and $\mathrm{pH}$ was established a very low correlation $(\mathrm{r}=0.28)$. As well, the number of microorganisms depends in a small scale by the humus content $(\mathrm{r}=0.03)$. The determination coefficient value $\left(\mathrm{R}^{2}=0.0841\right)$ indicated that total number of microorganisms variation depends on the proportion of $8.41 \%$ by the $\mathrm{pH}$ and humus content variations (Onet et al., 2011) (figure 1).

\section{Figure 1: Variation of the total number of bacteria depending} on $\mathrm{pH}$ values and humus content

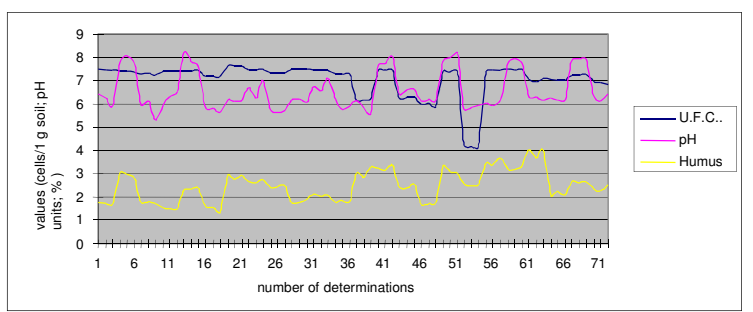

The correlation coefficients values indicated a low correlation between Actynomicetes, moisture content and $\mathrm{pH}$ values $(\mathrm{r}=0.06, \mathrm{r}=0.09)$. This dependence is not statistically (insignificant level). The determination coefficient value was $\mathrm{R}^{2}=0.0121$ (figure 2 ).

Figure 2: Variation of the total number of Actimomycetes depending on moisture content and $\mathrm{pH}$ values

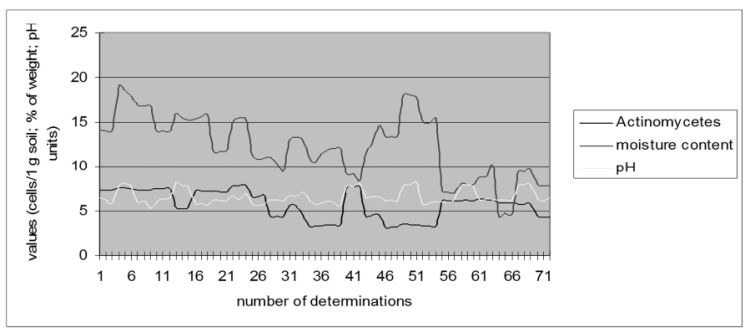

The correlation coefficient values indicated a low correlation (negative) between total number of yeastmould and moisture content $(\mathrm{r}=-0.12)$. An acceptable negative correlation was established between total number of yeast and mould and $\mathrm{pH}$ values $(\mathrm{r}=-0.32)$. The determination coefficient was $\mathrm{R}^{2}=0.1089$ (figure 3).

A low correlation was determined between Azotobacter and $\mathrm{pH}$ values $(\mathrm{r}=0.18)$ and a low correlation between these and ammonia nitrogen content $(\mathrm{r}=0.28)$. This dependence is very significant $(\mathrm{p}=0.1 \%)$. The numerical presence of Azotobacter depends in a proportion of $9.6 \%$ by the ammonia nitrogen content and $\mathrm{pH}$ variations $\left(\mathrm{R}^{2}=\right.$ 0.096) (figure 4).
Figure 3: Variation of the total number of yeast and mould depending on moisture content and $\mathrm{pH}$

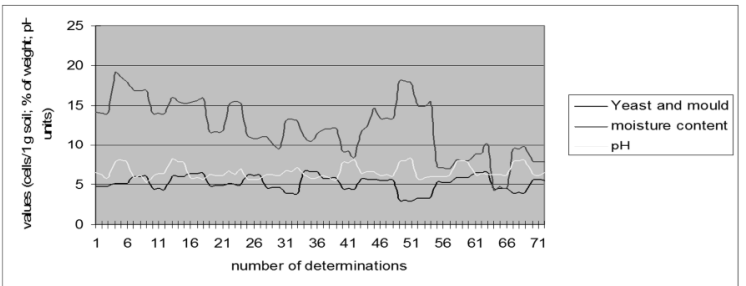

Figure 4: Variation of the total number of nitrogen fixing bacteria depending on ammonia nitrogen content and $\mathrm{pH}$ values

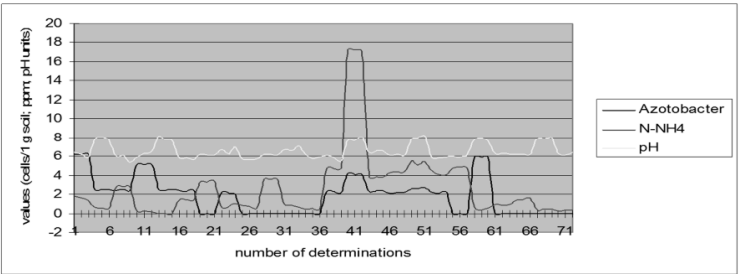

A low correlation was determined between the number of nitrifying bacteria, nitrates and humus content. The determination coefficient value was $\mathrm{R}^{2}=0.0169$. The numerical presence of nitrifying bacteria depends in a proportion of $1.69 \%$ by the nitric nitrogen content and humus content variation (Onet et al., 2011) (figure 5).

\section{Figure 5: Variation of the nitrifying bacteria depending on nitric nitrogen values and content in humus}

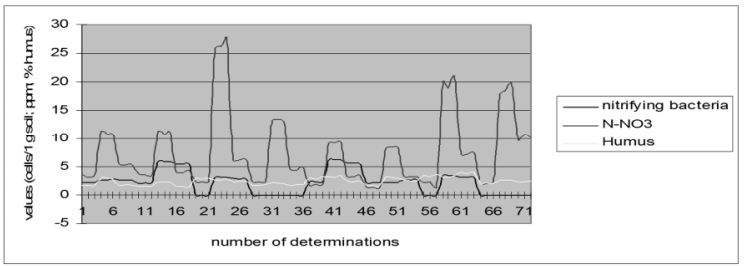

Between nitrifying bacteria number, ammonia nitrogen content and $\mathrm{pH}$ values was established a low correlation $(\mathrm{r}=0.32, \mathrm{r}=0.26)$ and a significantly dependence $(\mathrm{p}=0.1 \%)$. The determination coefficient was $\mathrm{R}^{2}=0.1444$ (figure 6).

Figure 6: Variation of the nitrifying bacteria depending on ammonia nitrogen content values and $\mathrm{pH}$ values

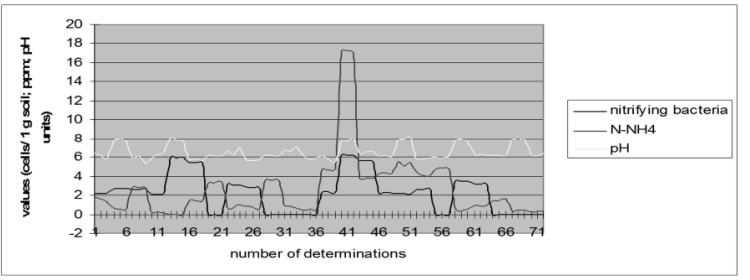




\section{CONCLUSIONS}

The microbiological analysis of soil samples from haplic luvisol suggest that microbiological processes of soil shows a seasonal fluctuations and changes determined in three different cropping systems, so the soil managements and seasons take part in the changes of microbial activity of soil. The results presented in this research shows that seasonal variations of soil microorganisms depend by changes in the soil chemistry. A low correlation was established between total number of microorganisms, $\mathrm{pH}$ and humus and between yeast and mould, $\mathrm{pH}$ and moisture content. Also, the numerical presence of nitrogen fixing bacteria depends by $\mathrm{pH}$ and ammonia nitrogen content and variations of nitrifying bacteria may be the results of ammonia nitrogen and $\mathrm{pH}$ variations.

\section{REFERENCES}

Alexander, M. (1965): Most probable-number method for microbial populations. [In: Black, C. A. et al. (eds.) Methods of Soil Analysis.] Ed. Am. Soc. Agron. Madison.

Atlas, R. M. (2004): Handbook of Microbiological Media. $3^{\text {rd }}$ edition. CRC Press. New York.

Digrak, M.-Kazanici, F. (1999): Efects of some organohophorus insecticides on soil microorganism. Faculty of Arts-Science. Turkey.

Drăgan-Bularda, M.-Kiss, S. (1986): Soil Microbiology. Univ. Babeş-Bolyai. Cluj-Napoca.

Onet, A. (2010): Research on the influence of fertilizers and pesticides pollution on biological activity and other properties of soil in the Plains Crisuri. PhD Thesis.

Onet, A.-Onet, C. (2010): Study of biological activity of haplic luvisol. Natural Resources and Sustainable Development. University of Oradea Publishing House.
Onet, A. (2010): Research on the influence of the use of chemical fertilizers and pesticides on the biological activity of the soils from Crisurilor Plains. Forests Magazine.

Onet, A.--Domuţa, C.-Brejea, R.-Onet, C. (2011): Study of the dependence between seasonal variation of micro-organisms and chemical properties of haplic luvisol. University of Oradea Annals. Environmental Protection Section. University of Oradea Publishing House. 16. 16:

Onet, A.-Onet, C. (2011): Numerical variation of the main groups of microorganisms monitored in haplic luvisol. University of Oradea Annals. Environmental Protection Section. University of Oradea Publishing House. 16. 16: 
